glass. It was unanimously decided that every attempt should be made to co-operate with other groups concerned with materials. It is hoped that, at a later stage, conferences will be held, in conjunction with other learned and professional societies, on a seriea of themes, oach of which involves consideration of a wide variety of materials, to stimulate the exchange of ideas and techniques betweon what are at present considered different disciplines. The Working Party is constituted as follows: Chairman, Mr. L. Holliday (Sholl Chemical Co., Ltd.); Honorary Secretary. Dr. P. E. Evans (Manchester Colloge of Science and Technology); Members, Dr. N. F. Astbury (British Ceramic Research Association), Prof. J. G. Ball (Imperial College of Science and Technology), Dr. T. H. Blakeley (The Morgan Crucible Co., Ltd.), Prof. R. W. Cahn (University College, Bangor), Dr. A. R. Collins (Cement and Concrete Research Association), Prof. A. H. Cottroll and Mr. J. A. Charles (University of Cambridge), Dr. J. I. Cox (A. Boake, Roberts and Co., Ltd.), Prof. R. W. Douglas (University of Sheffield), Dr. E. Eastwood (English Electric Co., Ltd.), Dr. G. A. R. Hartley (Courtaulds, Ltd.), Dr. J. M. Hutcheon (U.K. Atomic Energy Authority), Dr. N. P. Inglis (Imperial Metal Industries (Kynoch), Ltd.), Prof. R. Edgeworth Johnstone (University of Nottingham), Mr. A. Kennaway (B.T.R. Industries, Ltd.), Prof. A. J. Kennedy (College of Aeronautics, Cranfield), Mr. J. Luckins (British Paper and Board Industry Research Association), Mr. D. S. Mahon (Plastics Institute), Dr. J. W. Martin (University of Oxford), Prof. E. W. J. Mitchell (University of Reading), Mr. N. C. Moore (Plessey, Ltd.), Dr. P. Murray (U.K. Atomic Energy Research Establishment), Dr. J. F. Nye (University of Bristol), Mr. C. E. Phillips (National Engineering Laboratory), Dr. L. H. A. Pilkington (Pilkington Brothers, Ltd.), Dr. J. A. Pople (National Physical Laboratory), Mr. R. Llewollyn Rees (Central Electricity Generating Board), Prof. E. Rhoderick (Manchester College of Scienco and Technology), Mr. F. Roberts (U.K. Atomic Energy Research Establishment), Prof. T. K. Ross (Manchester (ollege of Science and Technology), Dr. G. C. Shipp (Brunel College of Technology), Dr. E. G. Stanford (Aluminium Laboratories, Ltd.). Dr. W. F. Watson (Rubber and Plastics Research Association), and Dr. J. G. Wistreich (British Iron and Steel Research Associa. tion).

\section{Economic Planning in France}

French Economic Planning doscribes briefly and clearly the origin and development of economic planning in France from the First (Monnot) Plan for modernization and equipment, 1946-53, to the final approval of the Fourth Plan (Pp. 12. London: Ambassade de France, Service de Presso et d'Information, 1963). It covers economic and social development 1962-65, visualizing a 24 per cent growth in gross internal production, an increased export drive, appreciable increase in collective oquipment for schools, hospitals, scientific research, town planning and country oquipment and a policy of regional development. The Second Plan, 1954-57, set production and investment targets for most sectors of the national economy, particularly the procossing industrios, agriculture and housing. The Third Plan, 1958-61, set out to restore the balance of the oconomy, which had boen upset by over-rapid progress under the Second Plan. The pamphlet also deseribos briefly the bodios responsible for planning, including the Commissariat Général du Plan and the Modernization Commissions, the procedure adopted in drawing up the Plans and the psychological and other factors which contribute to the effectiveness of tho Plans.

\section{U.S. National Institute of General Medical Sciences}

THE National Institute of General Medical Sciences, with Dr. Clinton C. Powell as its diroctor, has been founded. This brings the total of the National Institutes of Health,
U.S. Public Health Service, Bethesda, to nine. The new Institute was formerly the Division of General Medical Sciences of the National Institutes of Health. The Division was established in 1958 to help meot the increasing requirements of the Institutes' programmes of grants to non-federal modical schools, universities, and other medical institutions. Tho new Institute will bo responsible for administering, fostering and co-ordinating research in the scionces basic to medicine and biology, to public health, and to certain clinical sciences and biomedical studies not within the responsibility of the othor institutos.

\section{National Science Foundation Support for Research on Information Retrieval}

According to Scientific Information Notes, December 1962-January 1963 (No. 6, Vol. 4), an experimental study supported by the National Science Foundation showed that it is both practicable and desirable to convert the terminology used in some information systems to that being used by another and that the methodology developed can be applied to the preparation of a practical tool for the necessary conversion. Under a Foundation contract, the Datatrol Corporation, Maryland, is now developing a structured composite listing of the vocabularies used by the Atomic Enorgy Commission, the Armed Services Technical Information Agency and National Aeronautics and Space Administration with the view of compiling a dictionary of equivalents. Under another Foundation contract the character and clegree of use of the Chemical Engineering Thesaurus and the index data provided for articles in Chemical Engineering Progress - -both published by the American Instituto of Chemical Engineoring - are also being studied by Harner and Co., Washington, D.C., partly with the view of providing insight into the construction of thesauri and their efficiency as retrieval tools. The American Anthropological Association is condueting a rapid but thorough investiga. tion of its publishing situation: (1) to determino the extent and nature of existing stockpiles of data and manuscripts in anthropology and tho reasons why they have not been published; (2) to explore means for distributing such unpublished material; and (3) to suggest ways of integrat. ing and organizing the flow of anthropological materials, whether published or not.

The British Library of Political and Economic Science

THE annual report, 1961-62, of the British Library of Political and Economic Science records progress in the transfer of books to the Library Dopository established at Egham by the University, but staffing difficulties badly handicapped the work of the cataloguing department at senior and jumior levels (Pp. 15. London: British Library of Political and Economic Science, 1962). Acquisitions during the year totalled 7,353 treatises, 1,450 pamphlets, 3,551 non-serial Government publications (excluding British Parliamentary Papers and United States Public Documents) and 8,711 current serials. Bound volumes acquired totalled 11,405, 241 volumes of pamphlots bound bringing the total to 11,646 , from which 252 wero withdrawn or transforred to the Lending Library. Some 5,000 volumes of current acquisition were bound and 5,594 were bound, re-bound or repaired. The total of bound volumes in all libraries at July 31 , 1962 , was 432,208 of which 11,348 are in the Lending Library, 9,253 in study rooms, and 5,019 in the Shaw Library. Expenditure on treatises amounted to $£ 8,135$ with $£ 1,157$ on binding, on pamphlets $£ 148$, on non-sorial Government publications $£ 512$, on periodicals and other sorials $£ 8,357$ (including $£ 3,498$ on binding), while $£ 5,507$ was spent on current binding, and binding of arroars, ropairs and rebinding. The Lending Library issued 39,314 treatises, 1,371 works were lent to other libraries, and, of 862 readers' permits (262 for overseas), 327 were in foree on July 31,1962 . 